\title{
Büyükşehir İlçe Belediyelerinin Özerkliği: Şanlıurfa İlçe Belediyeleri Örneği
}

\author{
Abdullah ÇELİK \\ Prof. Dr., Harran Üniversitesi İktisadi ve İdari Bilimler Fakültesi, \\ Kamu Yönetimi Bölümü \\ abdullahcelik99@yahoo.com \\ Orcid ID: https://orcid.org/0000-0002-9413-7918

\section{Adile TAŞ} \\ Uzman, adiletas123@hotmail.com \\ Orcid ID: https://orcid.org/0000-0002-8571-5544
}

\begin{abstract}
Öz
Türkiye'de belediye yönetimi adına uygulanan iki farklı yönetim mevcuttur. Bir yanda metropoliten kentlere özgü olan büyükşehir belediye yönetimi uygulanırken bir yandan da diğer şehirlerde normal belediye yönetimi uygulanmaktadır. $\mathrm{Bu}$ iki farklı yapının varlığı yönetimde bazı sorunların yaşanmasına neden olmaktadır.

Bu bağlamda hazırlanmış olan bu çalışma, teorik ve alan araştırması olmak üzere iki ana bölümden oluşmaktadır. Teorik bölümde öncelikle özerklik ayrıntılı olarak ele alınmıştır. Daha sonra büyükşsehir belediyesi ile ilçe belediyeleri; vesayet, görev ve yetki paylaşımı, imar uygulama ve denetleme konuları özerklik bağlamında incelenmiştir. Şanlıurfa ili alan çalışması kapsamında ise; ilçe belediyelerinin büyükşehir ile ilişkilerini özerklik bağlamında irdelemek amacıyla hazırlanan ve uygulanan bir anket çalışmasına yer verilmiştir. $\mathrm{Bu}$ anket sonucunda elde edilen veriler değerlendirilerek ilçe belediyelerinin özerkliği hususunda yaşanan sorunlar ve bunların çözümüne yönelik önerilerde bulunulmuştur.
\end{abstract}

\footnotetext{
${ }^{1}$ Makale Geliş/Kabul Tarihi: 29.08.2019 / 14.04.2020

*Bu çalışma, Prof. Dr. Abdullah Çelik danışmanlığında Adile Taş tarafından Harran Üniversitesi Sosyal Bilimler Enstitüsü’nde tamamlanan “Büyükşehir İlçe Belediyelerinin Özerkliği” başlıklı Yüksek Lisans tezinden türetilmiştir.

Künye Bilgisi: Çelik, A. ve Taş, A.. (2020). Büyükşehir İlçe Belediyelerinin Özerkliği: Şanluurfa Illçe Belediyeleri Örneği. Kahramanmaraş Sütçü İmam Üniversitesi Sosyal Bilimler Dergisi, 17 (1), 294-320. DOI: 10.33437/ksusbd.613134
} 
Anahtar Kelimeler: Büyükşsehir Belediyesi, Büyükşehir İlçe Belediyesi, Özerklik, Yerel Özerklik.

\title{
The Self-Government of Metropolitan Sub-Provincial Municipalities: the Sample of Şanlıurfa's Sub-Provincial Municipalities
}

\begin{abstract}
There are two different managements which are applied for the management of municipality in Turkey. While the management model of metropolitan municipality specific to the metropolitan cities are applied, the normal municipality management is applied in the other cities. The existence of these different structure causes that some problems are seen.

This study which was made in that context consists of two main sections as the theoretical and field researches. Firstly, in the theoretical section; the selfgovernment was considered in details. Then, the metropolitan municipality and sub-provincial municipalities, tutelage, duty and authority sharing, the execution of zoning and supervision were examined in the context of autonomy. Within the scope of field study related to Şanlıurfa; a survey study which was prepared and applied in the purpose of reviewing the relationship between its sub-provincial municipalities and metropolitan municipality in the context of self-government was included. As the data which was obtained as a result of the survey was evaluated, the suggestions were provided for the problems which were seen in the self-government of sub-provincial municipalities and for their solutions.
\end{abstract}

Keywords: Metropolitan Municipality, Metropolitan Sub-Provincial Municipality, Autonomy, Local Autonomy.

\section{GíRiş}

İnsanların bir arada yaşamalarının bir gereği olarak ortaya çıkan kentler, sanayi devrimiyle birlikte hızlı bir dönüşüm ve gelişim yaşamıştır. Yaşanan tüm bu gelişmeler neticesinde kentler hızlıca büyümeye başlamıştır. Özellikle kentlerde, tarım dışında birçok alanda üretim yapılması kentleri cazibe merkezi haline getirmiş, kırsal alandaki geleneksel yapı çözülerek, kentsel alana kaymaya başlamıştır (Alıc1, 2012a: 1). Yaşanan bu gelişmeler sonucunda kırsal alanlardan 
kentlere özellikle büyük kentlere plansız ve yığılma halinde göç başlamıştır. $\mathrm{Bu}$ plansız yerleşmeler neticesinde belediye yönetiminin kent içerisinde vatandaşların ihtiyaç ve gereksinimlerine cevap verememesine sebep olmuştur. Gerek dış dinamikler (küreselleşme, bilgi ve teknoloji alanında yaşanan gelişmeler); gerekse iç dinamikler (tarımda makineleşme, kırsal alandan büyük kentlere yapılan göçler) olsun büyükşehirlerde yeni yönetim modelleri arayışlarına gidilmesine sebep olmuştur. Özellikle büyükşehirlere yönelik olarak büyükşehir belediye yönetimi ile ilgili pek çok kanun çıkarılmıştır. Büyükşehirlerde sorunların çözümü amacıyla ilk olarak 3030 sayılı Kanun daha sonra 2004 yılında 5216 sayılı Büyükşehir Belediye Kanunu çıkarılmıştır. Bu kanun ile belediyelerin idari ve mali özerkliğine değinilmiştir. Ayrıca bu kanun ile büyükşehir belediyesi ile ilçe belediyeleri arasındaki görev yetki ve sorumluluklarına da yer verilmiştir.

2012 yılında 6360 sayılı On Dört İlde Büyükşehir Belediyesi ve Yirmi Yedi İlçe Kurulması ile Bazı Kanun ve Kanun Hükmünde Kararnamelerde Değişiklik Yapılmasına Dair Kanun ile daha önce 16 olan büyükșehir belediyesi sayısı 30'a çıkarılmıştır. Yeni düzenleme ile büyükşsehir statüsüne kavuşan iller; Aydın, Balıkesir, Denizli, Hatay, Malatya, Manisa, Kahramanmaraş, Mardin, Muğla, Tekirdağ, Trabzon, Ordu, Van ve Şanlıurfa olmuştur. 2014 yerel seçimleri ile birlikte büyükşehir belediyesi statüsüne kavuşan Şanlıurfa ili bu çalışmanın konusudur. Şanlıurfa ilinde, 2014 yerel seçimlerinden sonra ilçe belediyesi statüsüne kavuşan ilçe belediyelerine yönelik, ilçe belediyelerinin özerkliğinin ne boyutta olduğu yapılan anket çalışması ile ortaya koyulmaya çalışılmıştır.

\section{ÖZERKLİK}

Özerklik, merkezden yönetimin ve bürokratik yönetimin olumsuz yönlerini azaltmak amaciyla düşünülen bir yönetim şeklidir. Yetkilerin tek elde toplanmas1, kararların üst düzeylerde merkez organlar tarafindan alınması, yürütmeyi geciktirip aynı zamanda hizmetlerin aksamasına sebep olmaktadır (Tortop, 1996: 3). Başka bir tanıma göre özerklik, kurumların kendi öz sorumlulukları altında ve ülke yararı doğrultusunda kendi hizmetlerini düzenleme haklarını ifade eder (Coşkun, 1996: 39). Diğer bir tanım ise; özerklik (otonomi) sözlük kelimesi itibariyle; bireylerin, grupların, örgütlerin, bölgelerin ve devletlerin, gerçek ve tüzel kişilerin haklarını ihlal etmeden ulusal ve uluslararası hukuk kuralları içerisinde kendilerini ilgilendiren alanlarda hedefler belirleyerek karar oluşturma yetkisi olarak tanımlanır (Çelik vd., 2008). Ayrıca özerklik, merkezden yönetimin bazı sakıncalarını gidermek veya azaltmak için düşünülen bir yönetim şeklidir. Yetkilerin tek elde toplanması, kararların üst düzey merkez organları tarafından alınması yürütmeyi geciktirmekte, uzmanlar ve işten anlayan kişilerin görüş ve düşüncelerinin yansımasını ve doğru kararlar alınmasını zorlaştırmaktadır (Kestane, 1996: 14). 


\section{Yerel Özerklik}

Yerel özerklik, yerel yönetimlere herhangi bir devlet veya merkezi yönetimin müdahalesi olmadan kendi yapısını, örgütünü ve işlerini düzenleyebilme konusunda tanınan kapsamlı yetkidir (Coşkun, 1996: 39). Bir başka tanıma göre yerel özerklik, yerel nitelikteki hizmetlerinin daha iyi görülmesi, katılımcı demokrasinin yaşama geçirilmesi doğrultusunda, yerel toplulukların, yerel nitelikteki işlerin kendi sorumlulukları altında özgürce seçerek oluşturdukları organlar aracıllğıyla buna uygun kaynaklara kavuşabilmeleri durumudur (Alodalı vd., 2007). Bir başka tanım ise, yerel özerklik, politik yönetsel sistemin mekânsal olarak sınırlandırılmış parçalarının alternatifler arasından seçilerek zorunlu kararları hazırlamak, bunları karara bağlamak ve uygulamasını gerçekleştirmek için harekete geçen eylemler olarak tanımlanır (Çelik vd., 2008).

Avrupa Yerel Yönetimler Özerklik Şartı'ndaki yerel özerklik tanımı ise, "özerk yerel yönetim kavramı, yerel makamların kanunlarla belirlenen sınırlar çerçevesinde, kamu işlerinin önemli bir bölümünü kendi sorumlulukları altında ve yerel nüfusun çıkarları doğrultusunda düzenleme ve yönetme hakkı" olarak tanımlanmıştır. Yerel özerklik, tarihsel gelişim süreci bazında yerel yönetimlere merkezi yönetim tarafindan verilmiş bir hak olmaktan ziyade, yerel yönetimlerin uzun ve zorlu mücadeleler sonucunda elde ettikleri bir haktır. Bu hak, yerel yönetimlere sadece yerel niteliğe sahip hizmetleri daha iyi bir şekilde yapmasına yardımcı olması için değil, aynı zamanda yerel toplumun kendi kendini yönetme yeteneğini geliştirmek, katılımcı ve demokratik bir yaşam şeklini kurmak ve zenginleştirmek için kullanır (Koç, 2015: 127).

Yerel özerkliğin iki durumu vardır: Bunlardan ilki, yerel yönetimlerin merkezi yönetimle olan ilişkileri ile alakalıdır. Yerel yönetimler bu ilişkilerinde merkezi yönetimden tamamen bağımsız olması söz konusu değildir. Önemli olan yerel birimlerin merkezi yönetimin bir müdahalesi olmadan kendi işlerini kendi kendilerine yapabilmeleridir. Kapsamlı bir özerklikten faydalanmaları gerekir. İkincisi ise, yerel yönetimlerle yerel halkın ilişkisidir. Halk tarafından seçilme yerel organların halkı gereği gibi temsil edebilmelerine, temsil yönetiminin bu nitelikte kişilerin seçilmesine elverişli olmasıdır (Keleş, 2016: 57).

\section{Mali Özerklik}

Mali özerklik, yerel yönetimlerde etkinlik, sosyal adalet ve tarafsılık, idarelerin görevlerini yapabilecek kadar mali kaynağa sahip olması ile mümkündür. Yerel yönetimlerde mali kaynak eksikliği özerkliğin sınırlanmasına 
ve merkezi yönetimin daha çok müdahalesine sebep olur. Yerel yönetimlerde mali yetersizlik, devlet tarafindan yapacağı eylemlerin engellenmesine veya yavaşlatılmasına sebep olan bir zeminin oluşmasına neden olabilmektedir. $\mathrm{Bu}$ anlamda gerekli mali kaynaklara sahip olmayan yerel yönetimler kendi hizmet alanlarında olan bazı görevleri merkezi yönetime aktarma eğilimine gidebilmektedir. Özellikle eğitim, sağlık ve kolluk hizmetleri bu alanda yer almaktadır (Tortop, 1996: 7).

Bir başka tanıma göre mali özerklik, özerk kuruluşların, merkezi yönetime bağlı kalmadan kendilerine verilen görevleri ve sorumlulukları yerine getirmeleri, ayrı mal varlığına ve gelir kaynaklarına sahip olmaları ve kanunların belirlediği şekilde kendi karar organlarına dayanarak harcama yapabilmeleri durumudur. Özerk bir idarenin sadece serbest karar alabilen organlarının olması yeterli değildir; aynı zamanda mali kaynaklarının olması ve bunların oran ve miktarın da belirleme yetkisine sahip olması gerekir (Ulusoy ve Akdemir, 2009: 263). Mali özerklik, yerel yönetimlerin merkezi yönetime muhtaç olmadan kendisine verilen görev ve yetkileri yapabilecek kadar serbest bir şekilde harcayabileceği yeterli gelir kaynaklarının olmasıdır (Koç, 2015: 137).

Yerel yönetimlerin merkezi idareden farklı ve ayr1 gelir kaynaklarının bulunması, kendilerine ait özel bütçelerinin olması özerk bir kuruluş olmalarının sonucudur. Mali özerklikten bahsedebilmek için yerel yönetimlerin kendi sınırları dâhilinde vergilendirme, harcama yapma, bütçe hazırlama, borçlanma ve yerel kamu hizmetlerini sunma gibi yetkilere sahip olması gerekir. Belediyelerin vatandaşlara etkin, kaliteli, ihtiyaçlarına yönelik hizmet sunması, sahip olduğu gelir kaynakları ile yakından ilgilidir. Mali özerkliğin göstergesi olarak, belediyelerin gelirleri ve bu gelirlerin birleşimi gösterilmektedir (Çelik, 2013: 22).

Yerel yönetimlerin hem kendi varlığını sürdürmesi hem de görevlerini yapabilmesi için düzenli mali kaynaklarının olması gerekir. Ancak pek çok ülkede verimli ve yüksek gelir artışı kaynakları merkezi idarenin elindedir. Yerel yönetimlere ise, vergi matrahı dar, toplanması zor, verimliliği düşük, kendi hizmetlerini karşılayamayacak düzeyde yetersiz gelir kaynakları kalmaktadır. Ayrıca yerel yönetimlerin yetersiz gelir kaynaklarına sahip olması demek; bu birimlerin görevlerinin yavaş yapılması veya hiç yapılamaması durumudur. Böylece yerel yönetimlerin merkezden gelecek olan kaynak aktarımına bağımlı hale gelmesine neden olur. Bu durum yerel yönetimlerin kendi organları aracılığıyla aldığı kararları uygulayabilmelerini ve merkezden bağımsız hareket etmelerini ciddi anlamda sinırlandırır (Ulusoy ve Akdemir, 2009: 264).

Mali açıdan karar alabilme düzeyine ulaşamamış, bütçesini kaynak yönünden geliştirme özerkliğine sahip olmayan yerel yönetimler, merkezi yönetime 
bağlıdırlar. Böyle bir yapıda mali özerklikten beklenen ölçüt sağlanamaz. Mali özerkliğin sağlanması için yerel yönetimlere kendi gelirlerini belirleme yetkisi verilmelidir. Üniter devletlerde, yerel yönetimlerce yapılan hizmetlerde kullanılan gelir kaynakları merkezi yönetim tarafindan kanun ile belirlenmektedir. Üniter devletlerde vergilendirme yetkisi genellikle merkezi yönetim tarafından yapılır. Buna göre vergilerin ve oranların belirlenmesinde yerel yönetimlerin çok fazla yetkisi olduğu söylenemez. Buna bağlı olarak sınırlı mali özerklik durumu oluşur. Sınırlı mali özerklik, vergilendirme konusunda yasama yetkisinin devletin elinde olan ve bunun sadece vergilerin tarh, tahakkuk ve tahsilini yerel yönetimlere bırakmasıdır. Böylece yerel yönetimler merkeze bağımlı hale gelir. Bu tür sistemlerde özerklik zayıf düzeydedir. Yerel yönetimlerin merkezin müdahalesi dışında faaliyette bulunması zordur. Türkiye'de sınırlı mali özerkliği yönetimde söz konusudur (Egeli ve Diril, 2012: 27-32).

\section{İdari Özerklik}

İdari özerklik, özerk kuruluşların karar organlarını seçimle iş başına getirebilmelerini, kendi organları aracılığı ile serbestçe karar alabilmelerini, işlerini dışarıdan herhangi bir müdahale olmadan kendi organları vasıtasıyla serbest karar verebilmelerini ve tüzel kişiliğe sahip olma durumunu ifade eder. $\mathrm{Bu}$ anlamda idari özerklik yerel yönetimlerin karar organlarının seçimle iş başına gelmeleri, bu organların serbestçe karar alıp uygulayabilmeleri ve yerel yönetimlerin tüzel kişiliğe sahip olmaları durumudur (Ulusoy ve Akdemir, 2009: 263).

İdari özerklik, yerel yönetimlerin kendi seçilmiş organları aracıllğıyla, merkezi yönetimin müdahalesi olmadan özgürce karar alıp uygulayabilmesidir. $\mathrm{Bu}$ anlamda idari özerkliğin sahip olduğu iki önemli koşul bulunmaktadır. Birincisi, ayrı bir tüzel kişiliğe sahip olan yerel yönetim organlarının seçimle iş başına gelmesi; ikincisi ise bu organların dışarıdan herhangi bir müdahale olmadan karar alıp uygulayabilmeleridir. Mahalli müşterek nitelikteki hizmetlerin halka en yakın birimler olan belediyeler tarafindan yapilması hem demokrasiye uygun hem de belediyelerin sahip olduğu idari ve mali özerklik açısından önemlidir. Yapılan hizmetleri daha önceden belirlenmiş yasal çerçevede kamu yararına yapması ve bu süreçte belediyelerin kendi karar organını seçimle kurması, vesayet denetimi ile sadece alınan kararların hukukilik denetimine tabi olması gerekir. Aksi halde belediyelerde idari özerkliğin varlığından bahsetmek mümkün olmayacaktır (Alıcı, 2013: 136).

5216 sayıl1 Kanunun 14 üncü maddesinde düzenlenen belediye meclisi kararlarının kesinleşmesi ile ilgilidir. $\mathrm{Bu}$ maddeye göre ilçe belediye meclislerinin bütçe ve imarla ilgili olan kararlar haricindeki kararları 
gerekçeleriyle birlikte büyükşehir belediye başkanına gönderilmekteydi. Belediye başkanı da yedi gün içerisinde gerekçesini de belirterek hukuka aykırı gördüğü kararı tekrar görüşülmek üzere geri gönderebiliyordu; ancak meclis üye tamsayısının salt çoğunluğu kararında israr etmesi durumunda ilgili karar kesinleşip yedi gün içinde büyükşehir belediyesine gönderiliyordu. Belediye başkanı da kesinleşen karar için 10 gün içerisinde yargıya başvurabiliyordu. İdari özerklik ve kanunun temel amacına uymayan bu düzenleme 06/03/2008 tarih ve 5747 sayılı Kanunun 3 üncü maddesi ile son bulmuştur. Kanunun aynı maddesi büyükşehir belediye meclisi ile ilçe belediyesinin kararlarının kesinleştiği tarihten itibaren en geç 7 gün içerisinde mülki idare amirine gönderileceği ve mülki idare amirine gönderilmeyen kararların da kesinleşmeyeceği hükmü 5216 sayılı Kanunun 14 üncü maddesine eklenmiştir. Buna göre ilçe belediye meclislerinin aldığı kararlar bütçe ve imar ile ilgili olanlar hariç, bu kararların onaylanmasında büyükşehir belediye başkanının görevine son verilmiştir. İlçe belediye meclisi kararlarının mahalli en büyük mülki idare amirine gönderilmesi bu suretle yürürlüğe girmesi hususu düzenlenmiştir.

\section{BÜYÜKŞEHIR BELEDIYYELERINDE İLÇE BELEDIYYELERINIIN ÖZERKLİĞ́I}

$\mathrm{Bu}$ başlıkta büyükşehir belediyeleri ile ilçe belediyeleri arasındaki ilişki özerklik bağlamında incelenmiştir. Büyükşehir belediyelerinin ilçe belediyeleri üzerinde denetim yetkileri, imar, bütçe, aralarındaki görev ve yetki paylaşımları anlatılmıştır.

Büyükşehir belediyesi ile ilçe belediyesi arasındaki ilişkilere bakıldığında, ilçe belediye meclisleri tarafindan imara ve bütçeye yönelik kararlarda büyükşehir belediyesinin bir vesayet makamı gibi davranmasını sağlayan bir düzenlemenin varlı̆̆ Koordinasyon Merkezi ve Alt Yapı Koordinasyon Merkezi gibi büyükşehir belediyesi ve merkezi yönetime ait kurumların temsilcileri karşısında, ilçe belediyelerinin sadece kendilerini ilgilendiren konularda katılması ve sonucunda alınan kararın ilçe belediyesi tarafından bağlayıcı olması yerel özerkliğe aykırı bir durumu ifade eder.

Güçlü bir başkan-pasif meclis, güçlü büyükşehir belediyesi güçsüz ve denetim altında bulunan ilçe belediyeleri şeklindeki bir sistemin varlığı dikkate alındığında "idari” ve "mali” özerkliğin Avrupa Yerel Yönetimler Özerklik Şartı'nın belirlediği sınıra ulaşamadığı, içi doldurulmamış bir söylem olarak 5216 sayılı Büyükşehir Belediyesi Kanunu'na girdiği söylenebilir. Bu söyleme bakılarak, büyükşehir belediyesinin asıl belediye ilçe belediyelerinin ikinci belediye olarak görülmesi, büyükşehir belediyesinin bir hayli güçlü konumda olması ilçe belediyelerinin idari ve mali kapasitesi ile yetki ve görev alanlarının 
bir hayli sınırlandırılmış olması, büyükşehir belediyesi sorunları arasında yer almıştır. Ayrıca ilgili mevzuat incelendiğinde büyükşehir belediye sistemi içerisindeki etkinliği vatandaşa yakın hizmet birimi olan ilçe belediyeleri tarafindan yerine getirilmesi gerekir. Ancak ilçe belediyeleri hizmet sunması bakımından gerekli yetki ve kaynağa sahip değildir. Buna bağlı olarak bazı faaliyetlerinde büyükşehir belediyesi denetimi altında görülmektedir (Alıc1, 2012a: 140- 142).

\section{Büyükşehir Belediyelerinin İlçe Belediyeleri Üzerindeki Denetim Yetkileri}

Başarılı bir yönetimin olmazsa olmazlarının başında denetim gelir. Yönetim kavramıyla bütünlük oluşturan, yönetimin vazgeçilmez bir parçasıdır. Denetim, yönetimin istenilen şekilde yürütülmesine, daha önceden belirlenen hedefleri zamanında ve verimli bir şekilde yapılmasına katkı yapar. Kurum tarafından yapılan işlerin, belli ilkelere uyum içerisinde olup olmadığını tespit eder ve yapılan kamu hizmetlerinin hukuk kuralları çerçevesinde yürütülmesini sağlar (Ekici ve Toker, 2005: 6). Yerel yönetimler üzerinde denetim önemlidir. Asıl konuya geçmeden önce, denetim çeşitlerinin tanımlarının açıklanması yerinde olacaktır.

Yönetsel denetim, yönetim kurum ve kuruluşları tarafindan yerel yönetimler üzerinde yapılan denetime yönetsel denetim denilir. Yerel yönetimlerin yetkilerini aşmayı önlemek amacıyla yapılır. Toplumların neredeyse tamamında merkezi yönetim ile yerel yönetimler birbirinden tamamen bağımsız değildir. Dolayısıyla merkezi yönetim ile yerel yönetim ayrılığından ziyade görev, yetki ve iş bölümü paylaşılması sonucu birbirini tamamlar. Yerel yönetimler bağımsız siyasal kuruluşlar değildir. Devlet yapısı içerisinde belli bir özerklikten yararlanan kuruluşlardır. Yönetsel denetim çeşitleri iç ve dış denetim olmak üzere iki tanedir.

İç denetim, ast-üst ilişkilerine bağlı olarak yapılan denetim türüdür. Hiyerarşik yapı içerisinde üst konumda bulunanlar tarafından astlarını denetlemeleri, yapılan eylem ve işlemlerini de kapsar. İç denetim yönetsel bir denetimdir. Yasal bir dayanağa ihtiyaç yoktur. İç denetimde hesapların, faaliyetlerin, iş ve işlemlerin ve buna dayanak olan kararların yerel yönetim birimleri tarafindan tespit ve incelemeye tabi tutulmasıdır. 5216 sayılı Büyükşehir Belediyesi Kanunu'na göre, belediyelerde iç denetim, belediye başkanı veya görevlendireceği iç denetçiler tarafından yapılır. Dış denetim, yönetim biriminin kendi tüzel kişiliği dışındaki makamlar tarafindan denetlenmesidir. Bu denetim; idari vesayet, ikili görev yoluyla denetim, mali yardımlar yoluyla denetim ve düzenleme, talimat verme yoluyla denetim şeklinde uygulanır (Ekici ve Toker, 2005: 7-8). İdari vesayet ise, genel anlamda merkezi yönetimin yerel yönetimin kararlarını ve faaliyetlerini 
denetleme yetkisidir. İdari vesayet, kamu düzenini, yurt bütünlüğünü sağlamak için kamu yararı amacıyla yasaların verdiği yetkiye dayanarak, merkezi yönetim örgütünün yerinden yönetim ve kamu hizmeti yönetimi tüzel kişilerinin; organları, işlemleri ve mali kaynakları üzerindeki denetimidir (Kavruk ve Yaylı, 2008: 3).

5216 sayılı Büyükşehir Belediyesi Kanunun 27 nci maddesi; "büyükşsehir kapsamındaki belediyeler arasında hizmetlerin yerine getirilmesi bakımından uyum ve koordinasyon büyükşsehir belediyesi tarafından sağlanacağı" hüküm altına alınmıştır. İlçe belediyeleri arasında hizmetlerin yürütülmesiyle ilgili herhangi bir sorun çıkması halinde büyükşehir belediye meclisine yönlendirici ve düzenleyici karar alma yetkisinin verileceği yine bu maddede geçmektedir. Buna göre büyükşehir belediyesinin ilçe belediyeleri arasında mevzuatta belirtilen konularda koordinasyonu sağlamak adına ilçe belediyeleri üzerinde kendine özgü bir denetim yetkisine sahip olduğu anlaşılmaktadır. Böyle bir denetim yetkisine sahip olması, büyükşehir belediyeleriyle ilçe belediyelerinin eşit statüde olmadığını gösterir. Başka bir ifadeyle ilçe belediyelerinin üzerinde merkezi idarenin "idari vesayet" yetkisinin yanı sıra ilçe belediyelerine göre daha "merkez" konumda olan büyükşehir belediyelerine ilçe belediyeleri üzerinde kullanılmak üzere bir çeşit idari vesayet yetkisi verilmiş bulunmaktadır (Alıcı, 2012b: 40). Büyükşehir belediyeleri kendilerini ilçe belediyelerinin hamisi olarak görmektedir. Kamu yönetiminde sıkça karşılaşılan, iş birliğini dışlayan, merkeziyetçi, yetki ve kaynak paylaşımı konusunda isteksiz yönetim anlayışı büyükşehir belediyelerinin ilçe belediyelerine karşı daha da baskıcı olmalarına neden olmuştur. Büyükşehir belediyeleri tarafından ilçe belediyeleri alt birim olarak görülmekte ve bu kuruluşların ayrı bir kuruluş kimliğine sahip oldukları unutulmaktadır (Karasu, 2013: 493).

İdari vesayet ve dış idari denetim kavramları dışında bu denetim yetkisinin idari vesayet denetimine benzediği yönünde ortak görüşler mevcuttur. Kimi akademisyen, idari vesayet kavramının kamu tüzel kişilerinin denetlenmesinde kullanılan yerleşik bir kavram olması sebebiyle bu denetim ilişkisinin idari vesayet olarak adlandırılmasında bir sakınca görmezken; kimi de yine aynı şekilde büyükşehir belediyesi ile ilçe belediyeleri arasında bu denetim ilişkisini "vesayet benzeri" bir denetime benzetmektedir. Bir kısmı da yine aynı şekilde söz konusu denetim yetkilerini belediyelerin ayrı tüzel kişiliklere sahip olması nedeniyle idari vesayete benzetmektedir. Görüldüğü gibi birçok akademisyen söz konusu denetim yetkisini idari vesayete benzetmektedir. Büyükşehir belediyesinin büyükşehir ilçe belediyeleri üzerinde belirli bir konuda sahip oldukları denetim yetkisinin tam olarak idari vesayet denetimi olmadığı, nev’i şahsına münhasır bir denetim olduğu söylenebilir (Alıc1, 2012b: 47-48).

Büyükşehir Belediyelerinin İlçe Belediyeleri Üzerinde İmar Denetimi 
5216 sayılı Kanun kapsamında denetim yetkilerinden en önemlilerinden biri de büyükşehir belediyelerinin imar denetim yetkisidir. 11 inci maddeye göre; büyükşehir belediyesi ilçe belediyelerinin imar uygulamalarını denetlemeye yetkilidir. Bu yetki, ilgili belediyeden her türlü bilgi ve belgeyi istemeyi ve bunları incelemeyi içerir. İstenilmiş olan bu belgeler ve bilgiler en geç iki hafta içerisinde büyükşehir belediyesine verilmek zorundadır. İmar uygulamaları denetim aşamasında iken, büyükşehir belediyeleri kamu kurum ve kuruluşlarından ve üniversitelerden yararlanabilirler. Denetimler sonucunda belirlenen eksiklikler ve aykırılıkların giderilmesi için üç ay süre verilir. $\mathrm{Bu}$ süre bazında gerekenin yapılmaması halinde, büyükşsehir belediyesi eksiklik ve aykırılıkları gidermeye yetkilidir. İzinsiz veya izin belgesine aykırı olarak yapılmış olan yapılar, gerekli düzenlemeyi yapmak üzere belediyeye bildirilir. İmara aykırı uygulama üç ay içerisinde düzeltilmediği takdirde büyükşehir belediyesi, 3194 sayılı İmar Kanunun 32 ve 42 nci maddeleri uyarınca kendilerine verilen yetkileri kullanırlar. Bu yetkiler; süre vererek düzeltme, inşaatı durdurma, yıkmaya veya cezalandırmaya ilişkin yetkilerdir. Büyükşehir belediyelerine verilmiş olan bu imar denetim yetkisi, birimler arasında koordinasyonu sağlamak ve yönetimde birliği sağlamaktan ziyade, bir hiyerarşik denetim niteliğindedir. Büyükşehir belediyelerine ilçe belediyeleri üzerinde, üstelik kentin geleceğini doğrudan etkileyen bir konuda çok ciddi bir denetim yetkisi verilmiştir. Bu yetki yerel özerkliği zedeleyici niteliktedir (Karasu, 2013: 489).

İmar konusunda ilçe belediyelerini ikinci plana atan bu uygulama; ilgili yere geri gönderme ve nitelikli çoğunlukla tekrar kabul mekanizmalarının da sisteme dâhil edilmesi, ilçe belediyesinin imar planına ilişkin düzeltme işleminin yetkide ve usulde paralellik ilkesi gereği yine ilçe belediyeleri tarafından yerine getirilmesi önemlidir. Bu yönde bir uygulama özerklik söylemine de uygun olacaktır (Alıc1, 2013: 138).

\section{Büyükşehir Belediyelerinin İlçe Belediyeleri Üzerinde Bütçe Denetimi}

5216 say1lı Kanunun 25 inci maddesine göre, büyükşehir belediye bütçesi ile ilçe belediyelerinden gelen bütçeler büyükşehir belediye meclisine sunulur ve büyükşehir belediye meclisi tarafindan yatırım ve hizmetler arasında bütünlük sağlayacak şekilde aynen veya değiştirilerek kabul edilir. Büyükşehir ilçe belediye bütçeleri, büyükşehir belediye meclisinde aynı toplantı döneminde ve birlikte görüşülerek karara bağlanır ve tek bütçe halinde basılır.

Büyükşehir belediye meclisi, ilçe belediyelerinin bütçelerini kabul ederken; bütçe metnindeki yasa ve yönetmeliklere aykırı maddeleri çıkarabilir, değiştirebilir, belediyelerin toplamaya yetkili olmadığı gelirleri çıkarabilir; yasal sınırlar üzerinde ya da altında belirlenmiş olan vergi ve harçların oran ve miktarlarını kanunda öngörülen sınırlara çekebilir, kesinleşmiş belediye borçları 
için bütçeye konulması gerekli olup da konulmamış ödeneği ekleyebilir, ortak yatırım izlencesine alınan yatırımlar için gerekli ödeneği ekleyebilir. Büyükşehir belediye meclisi tarafindan ilçe belediye bütçelerinde yapılan değişikliklere karşı 10 gün içinde Danıştay'a itiraz edilebilir. Bu tür itirazlar ise Danıştay tarafından 30 gün içerisinde karara bağlanır.

5216 sayılı Kanunda, büyükşehir belediyesinin gelirlerini düzenleyen 23 üncü maddesine göre genel bütçe vergi gelirleri tahsilâtı üzerinden ilçe belediyelerine verilen paylardan Cumhurbaşkanlığ 1 tarafından belirlenecek orandaki kısmının büyükşehir belediyesi için ayrılacağı öngörülmüştür. Ayrıca aynı madde de büyükşehir belediyesi tarafından tahsil edilen ve müssterek bahislerden gelen eğlence vergisinin \%50'sinin büyükşehir belediyesine \%20'sinin müşterek bahse konu olan yarışların yapıldığı yerin belediyesine \%30'unda diğer ilçe belediyelerine nüfuslarına göre dağıtılacağı belirtilmiştir. Yine benzeri bir yaklaşım, otoparkların işletmesinde elde edilen gelirin \%50'si büyükşehir belediyesine, geriye kalan \%50'si ise nüfuslarına göre ilçe belediyeleri arasında paylaşılır.

\section{Büyükşehir Belediyeleri ile İlçe Belediyeleri Arasında Görev ve Yetki Paylaşımı}

Büyükşehir belediyeleri ile ilçe belediyeleri arasında; görev ve yetki arasında belirsizlik, metropoliten olarak görülen kentsel alanlarda iki kademeli bir yönetim biçimi oluşturulmasında ortaya çıkabilecek sorunların başında yer alır. Özellikle büyükşehir belediyelerinin yetkilerinin geniş tutulması ve ilçe belediyeler üzerinde büyükşehir belediyesinin "dış idari denetim" ya da "iç idari vesayet" olarak adlandırılacak şekilde yetkilere sahip olması konunun önemini daha da arttırmaktadır (Erençin, 2005: 124).

5216 say1lı Kanunda görev bölüşümü sorunu net bir şekilde çözüme kavuşturulmamıştır. Kanunda öncelikle büyükşehir belediyelerine ait görev ve yetkiler sıralanmış olup, bu liste dışında kalan görevlerin ilçe belediyelerine ait olduğu hükmü yer almıştır. Diğer taraftan da 5216 sayılı Kanunda büyükşehir belediyelerine verilen görevler, 5393 sayılı Kanunla ilçe belediyelerine verilen görevlerle örtüşmektedir (Karasu, 2013: 494). Yapılan bu yeni düzenlemeye rağmen iki tüzel kişilik arasındaki sorunları çözümünde yeterli olmamıştır (Alıcı ve Kızılboğa, 2017: 259). Bu anlamda bu iki tüzel kişilik arasındaki sorunların çözümü adına mevzuatta görev ve yetkilerin açık bir şekilde belirtilmesi gerekmektedir.

Büyükşehir sınırları içinde belediyeler arasında görev ve yetki paylaşımını düzenleyen 7 nci maddeye göre, büyükşehir belediyesinin stratejik planı, yıllık hedefleri, yatırım programını ve bütçeyi hazırlarken ilçe belediyelerinin görüşlerinin alınacağı öngörülmüsstür. Bununla birlikte büyükşehir belediyelerine 
5216 sayılı Kanun ile verilmiş olan görevlerinde bir kısmını, büyükşehir belediye meclisinin kararı ve büyükşehir belediye başkanının uygun görmesi üzerine ilçe belediyelerine devredecek veya onlarla birlikte yapacaktır (Erençin, 2005: 121).

5216 sayılı Kanunda büyükşehir belediyesi sınırları içinde bulunan belediyeler arasında uyumu ve eş güdümü sağlamakta görevli kılınmış. Büyükşehir belediyesinin kendisine verilmiş görevleri, mali ve teknik imkânları çerçevesinde, nüfus ve hizmet alanları dikkate alarak, diğer belediyeler arasında yürütmek zorunda olduğu öngörülmüsstür. Aynı düzenlemede, büyükşehir kapsamındaki belediyeler arasında hizmetlerin yürütülmesi sırasında ortaya çıkacak ihtilafların büyükşehir belediye encümeninin yönlendirici ve düzenleyici kararıyla giderilmeye çalışılacağı belirtilmiştir.

\section{ALAN ARAŞTIRMASI}

\section{Verilerin Toplanması ve Metodoloji}

Çalışmanın kapsamında yer alan Şanlıurfa ilçeleri Akçakale, Birecik, Bozova, Ceylanpınar, Eyyubiye, Halfeti, Haliliye, Harran, Hilvan, Karaköprü, Siverek, Suruç ve Viranşehir'de anket uygulaması yapılmıştır. Büyükşehir belediye meclis üyelerine ve ilçe belediye meclis üyelerine 6360 sayılı Kanun ile büyükșehir olan Şanlıurfa büyükşehir belediyesi ve ilçe belediye meclis üyelerine özerklik bağlamında büyükşehir ve ilçe belediyeleri ilişkilerini tespite yönelik sorular sorularak bu konuya üyelerin bakış açıları belirlenmeye çalışılmıştır.

Anket hazırlama süreci (37 soru) üç aylık zaman sürecinde tamamlanmıştır. Bu sürecin ardından 2019 Ocak ve Şubat aylarında daha önceden belirlenmiş olan kişi sayısına araştırma örnekleminde yer alan anketler uygulanmıştır. Şanlıurfa büyükşehir belediye meclis üyeleri ile ilçe belediye meclis üyelerinin bulunduğu 13 ilçede anketler ilgili kişiler tarafindan doldurularak anket işlemi sona ermiştir.

Uygulanan anketlerdeki verilerin analizinin bilgisayara aktarılması için anketler tek tek gözden geçirilmiş ve anketlere veri kodlama işlemi yapılmıştır. Veriler SPSS (25.0) paket programı kullanılarak frekans biçiminde analizler yapılmıştır.

\section{Araştırmanın Evren ve Örneklemi}

Çalışmanın ana evrenini Şanlıurfa ili ve Akçakale, Birecik, Bozova, Ceylanpınar, Eyyubiye, Halfeti, Haliliye, Harran, Hilvan, Karaköprü, Siverek, Suruç ve Viranşehir olmak üzere 13 ilçesi oluşturmaktadır. Çalışmada üzerinde durulan önemli bir konu tüm ilçe belediyelerini kapsayan bir çalışma olmasıdır. 6360 sayılı Kanunla büyükşehir statüsüne kavuşan Şanlıurfa ili, yaşanan bu 
değişimler neticesinde il dâhilinde yeni 3 ilçe ile 13 ilçe belediyesine kavuşmuştur.

Evren olarak 13 ilçede, büyükşehir belediye meclisi üyeleri ile ilçe belediye meclis üyeleri seçilmiştir. Evren olarak seçilen büyükşehir belediye meclis üyesi ve ilçe belediye meclis üyesi sayılarını toplamı; 82'si büyükşehir belediye meclisi ve 256'sı da ilçe belediye meclis üyesi olmak üzere toplam 338 kişidir.

Örneklem olarak 338 kişiden 216 kişiye ulaşılmış, başka bir ifadeyle bilimsel açıdan sayısal olarak ulaşılması hedeflenen kitleye ulaşılmış ve bu kitle anketleri cevaplamıştır. Örnekleme, Şanlıurfa ilinin tüm ilçeleri dâhil edilmiştir. Ancak 2016 yılında Türkiye'nin bazı il ve ilçelerine kayyum belediye başkanı atanmış ve kayyum atanan yerlerde Şanlıurfa'nın bazı ilçeleri de yer almaktadır. Şanlıurfa'da kayyum atanan ilçeler: Suruç, Bozova, Halfeti ve Viranşehir'dir. Dolayısıyla bu ilçelerin özel durumundan dolayı bu ilçelerde anket uygulaması belediye meclisi üyesi sıfatı ile çalışan belediyenin kendi personeli ile yapılmıştır.

\section{Katılımcıların Demografik Özellikleri}

Araştırmaya katılan katılımcıların cinsiyete göre dağılımları incelendiğinde \%9,3'ünün kadın, \%90,7'sinin erkek olduğu görülmektedir. Ankete katılan toplam kişi sayısı açısından bakıldığında 216 kişiden 20'sinin kadın olduğu görülmektedir. Belediye meclisi üyelerinin büyük bir çoğunluğunun erkek nüfusunun oluşturduğu, kadın nüfusunun yok denecek kadar az olduğu görülmektedir.

Katılımcıların hangi belediye meclisi üyesi olduğuna göre dağılımları incelendiğinde \%11,6'sının Akçakale, \%6,5'inin Birecik, \%5,6'sının Bozova, \%10,2'sinin Ceylanpınar, \%10,2'sinin Eyyübiye, \%4,2'sinin Halfeti, \%9,7'sinin Haliliye, \%6,5'inin Harran, \%4,2'sinin Hilvan, \%8,8'inin Karaköprü, \%6,5'inin Siverek, \%7,9'unun Suruç ve \%8,3'ünün Viranşehir olduğu tespit edilmiştir.

Katılımcıların mensubu olduğu siyasal partiye göre dağılımları incelendiğinde \%82,4'ünün Adalet ve Kalkınma Partisi, \%2,8'inin Milliyetçi Hareket Partisi, \%13,4'ünün Halkların Demokratik Partisi ve \%1,4'ünün diğer siyasal partilere mensup olduğu tespit edilmiştir. Mensubu olunan siyasi partiye göre dağılımlarına bakıldığında il genelinin büyük çoğunluğunun Adalet ve Kalkınma Partisi'nden olduğu görülmektedir. Ayrıca yine mensubu olunan siyasi partiye göre dağılımlarına bakıldığında il genelinde Cumhuriyet Halk Partisi üyelerin olmadığı, Halkların Demokratik Partisi dışında diğer siyasal partilerin de katılımlarının çok az olduğu tespit edilmiştir.

Katılımcıların yaşlarına göre dağılımları incelendiğinde \%1,9'unun 18-25 yaş aralığında, \%12,0'ının 25-30 yaş aralığında, \%11,6'sının 31-36 yaş aralığında, 
\%17,1'inin 37-42 yaş aralığında, \%19,0'ının 43-48 yaş aralığında, \%15,3'ünün 49-54 yaş aralığında, $\% 23,1$ 'inin 54 yaş ve üstünde olduğu görülmüştür. Buna göre ankete katılan ilçe belediye meclis üyelerinin 40 ile 50 yaş arasında yoğunluk kazandığı söylenebilir.

Katılımcıların eğitim durumuna göre dağılımları incelendiğinde \%25,9'unun ilköğretim, \%31,5'inin lise ve dengi, \%8,8'inin önlisans, \%29,6'sının lisans, $\% 4,2$ 'sinin ise lisansüstü olduğu tespit edilmiş̧tir. Ankete katılanlar eğitim durumlarına göre incelendiğinde, ankete katılan ilçe belediye meclis üyelerinin büyük bir çoğunluğunun lise ve dengi okullardan mezun olduğu görülmektedir. Ayrıca ilköğretim mezunlarının oranlarına bakıldı̆̆ında \%25,9 olduğu görülmektedir. Bu oran azımsanmayacak niteliktedir.

Katılımcıların mesleklerine göre dağılımları incelendiğinde \%13,9'unun esnaf, \%23,1'inin çiftçi, \%4,2'sinin iş̧̧i, \%18,5'inin serbest meslek, \%7,4'ünün emekli, \%10,2'sinin yönetici, \%11,1 memur, \%11,6'sının ise diğer meslek grubunda olduğu tespit edilmiştir. Genel anlamda bakıldığı zaman ankete katılanların çeşitli meslek gruplarından olduğu söylenebilmektedir. Özellikle esnaf, çiftçi ve serbest meslek gruplarının yoğunlukta olduğu görülmektedir.

\section{Katılımcıların İfadelere Verdiği Cevaplar}

Tablo 1'de Şanlıurfa ilçe belediye meclis üyelerinin aşağıdaki sorulara verilmiş olan cevaplara yüzdelik (frekans) analizi uygulanmıştır.

Tablo: 1: Katılımcıların İfadelere Verdiği Cevaplara Göre Dağılımı

\begin{tabular}{|c|c|c|c|c|c|c|c|c|c|c|}
\hline & & 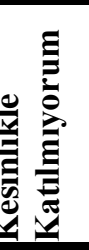 & & 氞 & 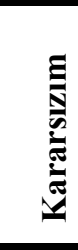 & & & 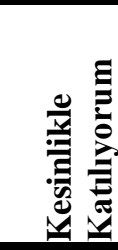 & & \\
\hline & & 1 & I & $\%$ & n & $\%$ & n & $\%$ & 1 & $\%$ \\
\hline $\begin{array}{l}\text { Büyükşehir } \\
\text { belediye meclisi } \\
\text { üyeleri hem } \\
\text { büyükşehir hem de } \\
\text { ilçe belediye } \\
\text { meclisi üyesi } \\
\text { olduklarından, } \\
\text { büyükşehir ve ilçe } \\
\text { çıarları }\end{array}$ & 25 & 11,6 & 34 & 15,7 & 24 & 11,1 & 97 & 44,9 & 36 & 16,7 \\
\hline
\end{tabular}


çatışmasında kendi

ilçe çıarlarına

öncelik

vereceklerdir.

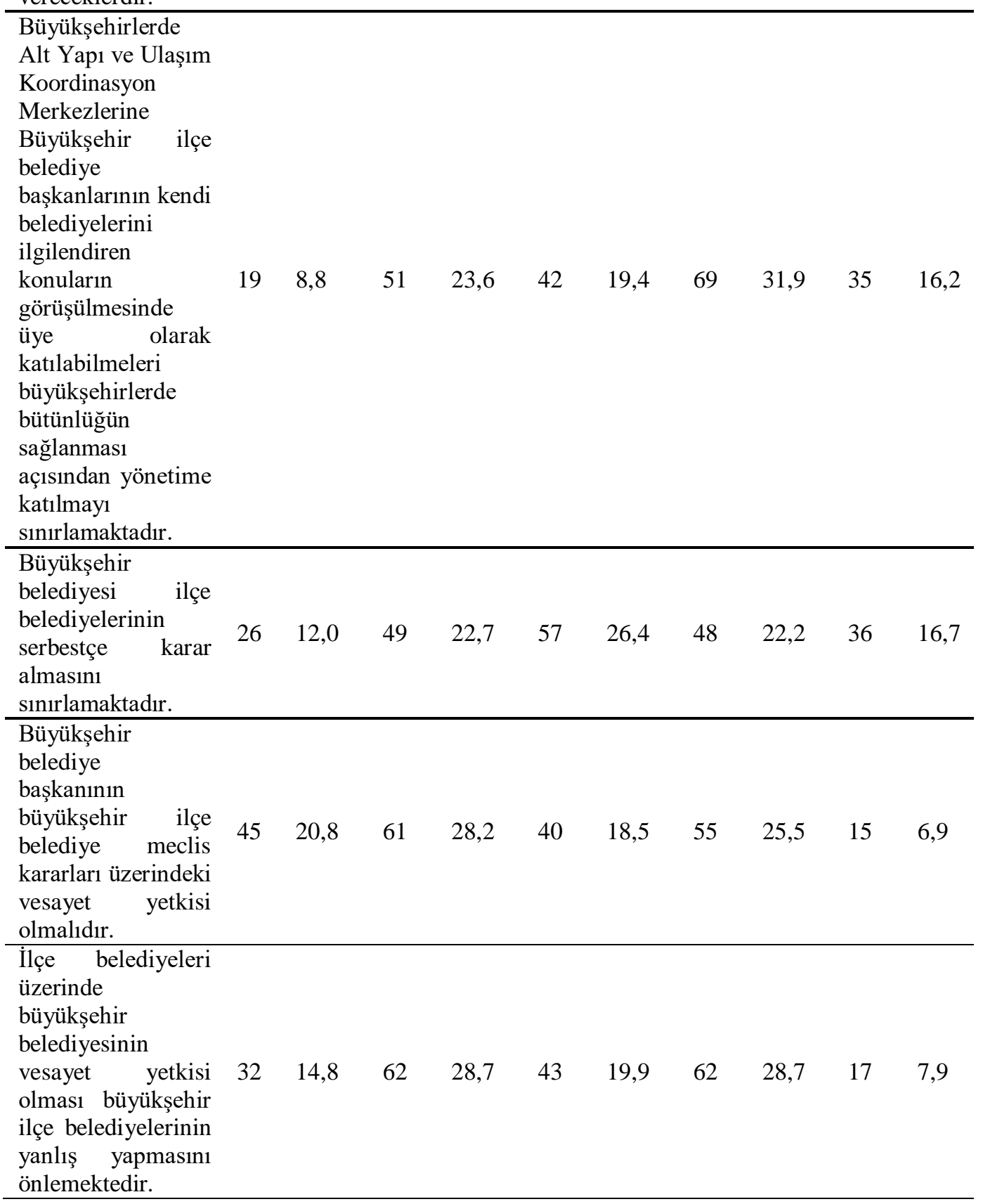




\begin{tabular}{|c|c|c|c|c|c|c|c|c|c|c|}
\hline $\begin{array}{l}\text { Büyükşehir } \\
\text { belediyesi ile ilçe } \\
\text { belediyeleri } \\
\text { arasında görev ve } \\
\text { yetkiler net bir } \\
\text { şekilde } \\
\text { tanımlanmamıstır. }\end{array}$ & 29 & 13,4 & 54 & 25,0 & 47 & 21,8 & 52 & 24,1 & 34 & 15,7 \\
\hline $\begin{array}{l}\text { Büyükşehir } \\
\text { belediyesi ile ilçe } \\
\text { belediyeleri } \\
\text { arasındaki ilisski; bir } \\
\text { ast-üst ilişkisi } \\
\text { olarak } \\
\text { nitelendirilebilir. }\end{array}$ & 20 & 9,3 & 40 & 18,5 & 45 & 20,8 & 80 & 37,0 & 31 & 14,4 \\
\hline 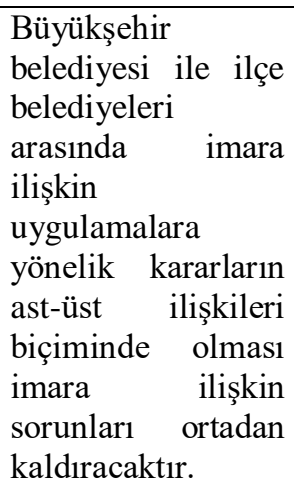 & 41 & 19,0 & 34 & 15,7 & 61 & 28,2 & 58 & 26,9 & 22 & 10,2 \\
\hline $\begin{array}{l}\text { İmar uygulama ve } \\
\text { denetleme } \\
\text { yetkisinin } \\
\text { büyükşehir } \\
\text { belediyesinde } \\
\text { olması büyükşehir } \\
\text { sınırları içerisinde } \\
\text { bütünlüğ̈̈ } \\
\text { sağlaması } \\
\text { açısından doğrudur. }\end{array}$ & 30 & 13,9 & 35 & 16,2 & 43 & 19,9 & 81 & 37,5 & 27 & 12,5 \\
\hline \begin{tabular}{lr} 
Büyükşehir & ilçe \\
\multicolumn{2}{l}{ belediye meclisleri } \\
tarafindan & alınan \\
imara & ilişkin \\
kararların & \\
büyükşehir & \\
belediye & meclisi \\
tarafindan & nazım \\
imar & plânına \\
uygunluğu & \\
yönünden &
\end{tabular} & 27 & 12,5 & 32 & 14,8 & 44 & 20,4 & 89 & 41,2 & 24 & 11,1 \\
\hline
\end{tabular}




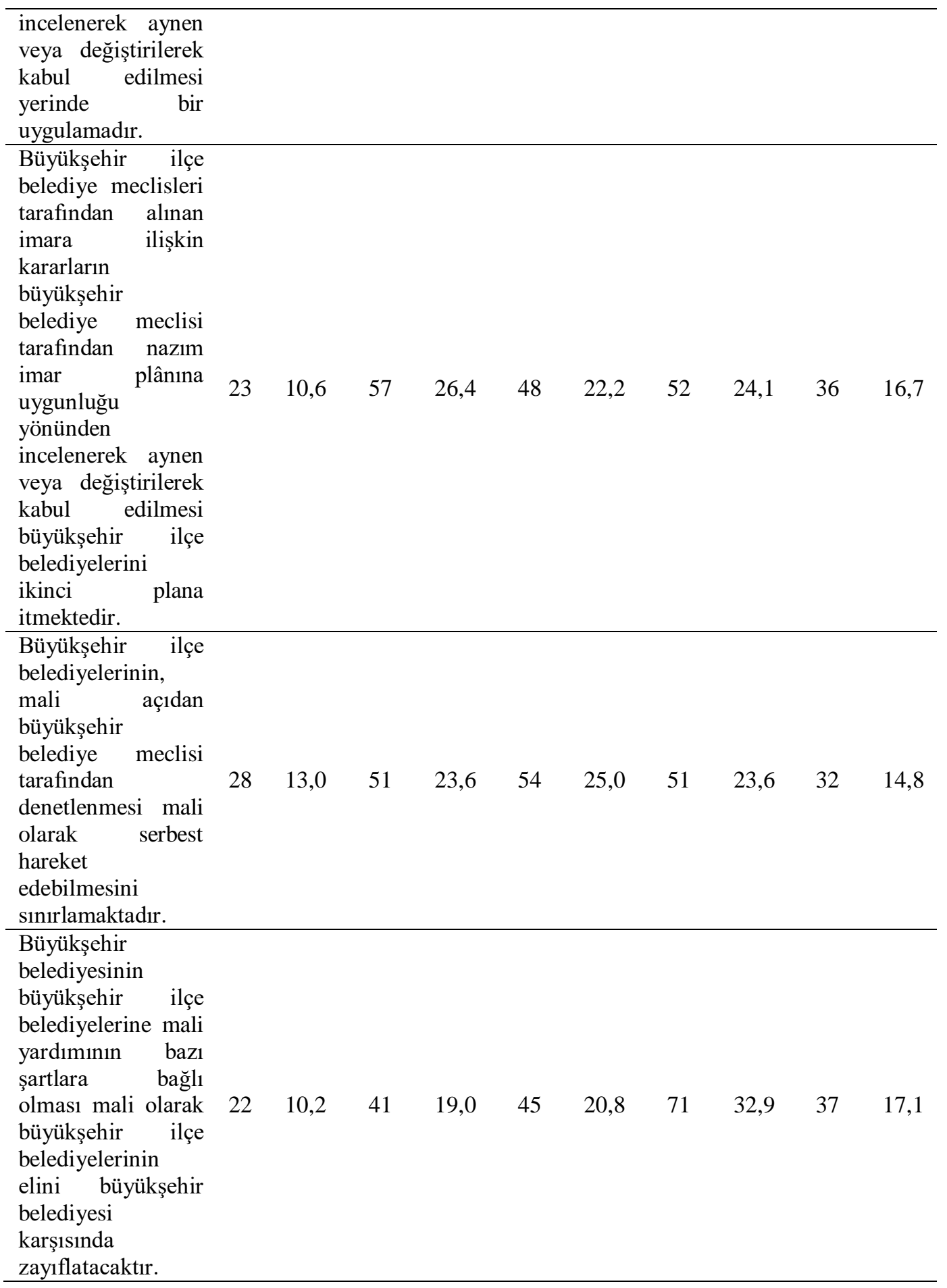


A. Celik - A. Taș

Büyükșehir İlce Belediyelerinin Özerkliği...

\begin{tabular}{|c|c|c|c|c|c|c|c|c|c|c|}
\hline $\begin{array}{l}\text { Büyükşehir } \\
\text { belediye meclisi } \\
\text { karar alırken ilçe } \\
\text { belediyelerinin } \\
\text { görüss ve taleplerini } \\
\text { dikkate alır. }\end{array}$ & 32 & 14,8 & 34 & 15,7 & 37 & 17,1 & 88 & 40,7 & 25 & 11,6 \\
\hline $\begin{array}{l}\text { Büyükşehir } \\
\text { belediye meclisi } \\
\text { aldığı kararlarında } \\
\text { ilçe belediyelerinin } \\
\text { çıkarlarını gözetir. }\end{array}$ & 29 & 13,4 & 50 & 23,1 & 45 & 20,8 & 71 & 32,9 & 21 & 9,7 \\
\hline $\begin{array}{l}\text { Büyükşehir ilçe } \\
\text { belediye } \\
\text { meclislerinin aldığı } \\
\text { kararların } \\
\text { yürürlüğe } \\
\text { girebilmesi için } \\
\text { büyükşehir } \\
\text { belediye başkanına } \\
\text { gönderilmesi } \\
\text { uygulamasının } \\
\text { kaldırılması } \\
\text { büyükşehir } \\
\text { genelinde } \\
\text { birlikteliğin } \\
\text { sağlanması } \\
\text { konusuna zarar } \\
\text { vermiştir. }\end{array}$ & 23 & 10,6 & 42 & 19,4 & 84 & 38,9 & 52 & 24,1 & 15 & 6,9 \\
\hline $\begin{array}{l}\text { İlçe belediye } \\
\text { meclislerinde } \\
\text { alınan kararların } \\
\text { (imar ve bütçe } \\
\text { hariç) yürürlüğe } \\
\text { girebilmesi için } \\
\text { mülki idare amirine } \\
\text { gönderilmesi } \\
\text { mecburiyetinin } \\
\text { meclis üzerinde } \\
\text { herhangi bir baskı } \\
\text { oluşturmadığını } \\
\text { düşünüyorum. }\end{array}$ & 27 & 12,5 & 28 & 13,0 & 46 & 21,3 & 86 & 39,8 & 29 & 13,4 \\
\hline 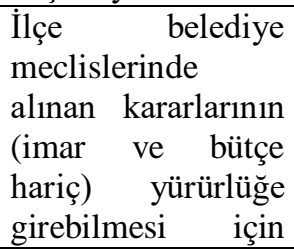 & 29 & 13,4 & 40 & 18,5 & 63 & 29,2 & 67 & 31,0 & 17 & 7,9 \\
\hline
\end{tabular}




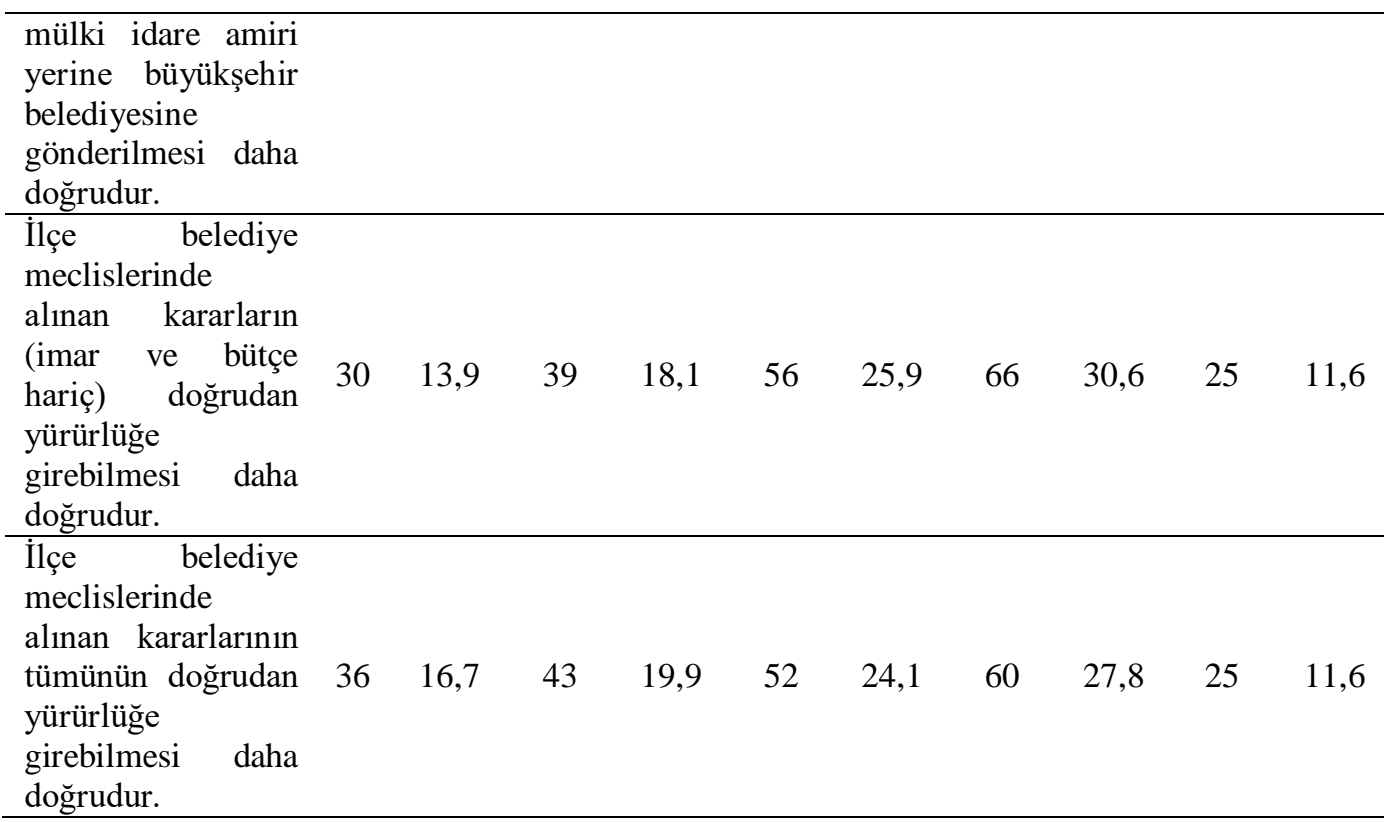

İlçe belediye meclis üyelerinin "Büyükşehir belediye meclisi üyeleri hem büyükşehir hem de ilçe belediye meclisi üyesi olduklarından büyükşehir ve ilçe çıkarları çatışmasında kendi ilçe çıkarlarına öncelik vereceklerdir" ifadesine verdiği cevaplara göre dağılımları incelendiğinde, \% 11,6's1 kesinlikle katılmiyorum, \% 15,7'si katılmiyorum, \% 11,1'i kararsızım demeleri hem kendi ilçelerinin lehine olan işlerde ilçesi için çalışan üyeler olduğunu hem de ilçeleri dışında illerine de gerçek anlamda değer veren üyeler olduğunu ortaya koymaktadır. Ancak geriye kalan \%44,9'u katıliyorum cevabını verirken, $\% 16,7$ 'si ise kesinlikle katılıyorum cevabını vermesi kendi ilçe çıkarlarını ön planda tuttuklarını göstermektedir.

İlçe belediye meclis üyelerinin "Büyükşehirlerde Alt Yap1 ve Ulaşım Koordinasyon Merkezlerine Büyükşehir ilçe belediye başkanlarının kendi belediyelerini ilgilendiren konuların görüşülmesinde üye olarak katılabilmeleri büyükşehirlerde bütünlüğün sağlanması açısından yönetime katılmayı sinırlamaktadır" ifadesine verdiği cevaplara göre dağılımları incelendiğinde, \% 8'i kesinlikle katılmıyorum, \% 23,6's1 katılmıyorum derken bu görüşü desteklemedikleri görülmektedir. Oysa katılımcıların \%31,9'unun katılıyorum, \%16,2'sinin de kesinlikle katılıyorum şeklinde fikir ortaya koyması bu görüşü desteklediklerini göstermektedir. Ayrıca katılımcıların \%19,4'ünün de bu konuda kararsız kaldıkları belirtilebilmektedir. 
İlçe belediye meclis üyelerinin "Büyükşehir belediyesi ilçe belediyelerinin serbestçe karar almasını sınırlandırmaktadır" ifadesine verdiği cevaplara göre dağılımları incelendiğinde, \%12'si kesinlikle katılmıyorum, \%22,7'si katılmıyorum, \% 26,'ü kararsızım, \% 22,2'si kat1liyorum, \% 16,7'si kesinlikle katılıyorum cevabını vermiştir. Buna göre büyükşehir belediyesinin ilçe belediyelerinin kararlarına karışıp karışmadığı konusunda net bir fikir ortaya koyulamadığı söylenebilmektedir.

İlçe belediye meclis üyelerinin "Büyükşehir belediye başkanının büyükşehir ilçe belediye meclis kararları üzerindeki vesayet yetkisi olmalıdır" ifadesine verdiği cevaplara göre dağılımları incelendiğinde \% 20,8'i kesinlikle katılmıyorum, \% 28,2'si katılmıyorum, \% 18,5'i kararsızım, \% 25,5'i katılıyorum, \% 6,9'u kesinlikle katılıyorum cevabını vermiştir. Buna göre ankete katılan ilçe belediyelerinin bir kısmının büyükşehir belediye başkanının ilçe belediyeleri üzerinde vesayet yetkisi olmasını kabul etmedikleri görülmektedir.

İlçe belediye meclis üyelerinin "İlçe belediyeleri üzerinde büyükşehir belediyesinin vesayet yetkisi olması büyükşehir ilçe belediyelerinin yanlış yapmasını önlemektedir" ifadesine verdiği cevaplara göre dağılımları incelendiğinde, \% 14,8'i kesinlikle katılmıorum, \% 28,7'si katılmıyorum, \% 19,9'u kararsizım, \% 28,7' kat1lyyorum, \% 7,9’u da kesinlikle katıliyorum cevabını vermiştir. Buna göre bu ifadeye katılan ve katılmayanlar eşit çıkmıştır. Çoğunluğun bir kısmı büyükşehirde vesayet yetkisinin olması ilçe belediyelerinin yanlış yapacağına savunurken diğer bir kısmı da tam tersi düşünceyi savunmuştur.

İlçe belediye meclis üyelerinin "Büyükşehir belediyesi ile ilçe belediyeleri arasında görev ve yetkiler net bir şekilde tanımlanmamıştır" ifadesine verdiği cevaplara göre dağılımları incelendiğinde, \% 13,4'ü kesinlikle katılmıyorum, \%25,0'i katılmıorum, \% 21,8'i kararsızım, \%24,1'i katılıyorum, \% 15,7'si kesinlikle katılıyorum cevabını verdiği görülmüştür. Buna göre büyükşehir belediyesi ile ilçe belediyeleri arasında görev ve yetkilerin net bir şekilde tanımlandığı ankete katılanlar tarafından savunulmuştur. Verilen bu cevaba bakılarak ilçe belediyelerince görev ve yetki paylaşılması konusunda büyükşehir belediyesi ile sorun yaşamadığını çıkarımı yapılabilmektedir.

İlçe belediye meclis üyelerinin "Büyükşehir belediyesi ile ilçe belediyeleri arasındaki ilişki; bir ast-üst ilişkisi olarak nitelendirilebilir" ifadesine verdiği cevaplara göre dağılımları incelendiğinde, \%9,3'ü kesinlikle katılmıyorum, \%18,5'i katılmıorum, \%20,8'i kararsızım, \%37,0'i katılıyorum, \% 14, 4'ü kesinlikle katılıyorum cevabını vermiştir. Görülen o ki ankete katılan katılımcılar büyükşehir belediyesi ile ilçe belediyeleri arasındaki ilişkiyi bir ast-üst ilişkisi olarak nitelendirmektedir. 
İlçe belediye meclis üyelerinin "Büyükşehir belediyesi ile ilçe belediyeleri arasında imara ilişkin uygulamalara yönelik kararların ast-üst ilişkileri biçiminde olması imara ilişkin sorunları ortadan kaldıracaktır" ifadesine verdiği cevaplara göre dağılımları incelendiğinde \% 9,0'u kesinlikle katılmıyorum, \% 15,7'si katılmıyorum, \% 28,2'si kararsızım, \% 26,9'u kat1liyorum, \%10,2'si de kesinlikle katılıyorum cevabını vermiştir. Buna göre büyükşehir belediyesinin ilçe belediyelerinin imara ilişkin sorunlarının olmamasında ilişkilerinin ast-üst şeklinde olmasından kaynaklanması noktasında bir fikir birliğine varamadıkları görülmüştür.

İlçe belediye meclis üyelerinin "İmar uygulama ve denetleme yetkisinin büyükşehir belediyesinde olması büyükşehir sınırları içerisinde bütünlüğü sağlaması açısından doğrudur" ifadesine verdiği cevaplara göre dağılımları incelendiğinde, \% 13,9'u kesinlikle katılmıyorum, \% 16,2'si katılmıyorum, \% 19,9' u kararsızım, \%37,5'i katılıyorum, \%12,5'i kesinlikle katılıyorum cevabını vermiştir. Buna göre imara ilişkin kararların uygulama ve denetleme yetkisinin büyükşehir belediyesinde olması, büyükşehir sınırlarında bütünlügü sağlamaktadır.

İlçe belediye meclis üyelerinin "Büyükşehir ilçe belediye meclisleri tarafından alınan imara ilişkin kararların büyükșehir belediye meclisi tarafından nazım imar planına uygunluğu yönünden incelenerek aynen veya değiştirilerek kabul edilmesi yerinde bir uygulamadır" ifadesine verdiği cevaplara göre dağılımları incelendiğinde, \% 12,5'i kesinlikle katılmıyorum, \% 14,8'i katılmıyorum, \% 20,4'ü kararsızım, \% 41,2'si katılıyorum ve \% 11,'1'i ise kesinlikle katılıyorum cevabını vermiştir. Verilen cevaplara bakıldığında büyükşehir belediye meclisinin ilçe belediye meclislerince alınan nazım imar planı üzerindeki bu yetkisinin yerinde bir uygulama olduğunu ortaya çıkarmıştır.

İlçe belediye meclis üyelerinin "Büyükşehir ilçe belediye meclisleri tarafından alınan imara ilişkin kararların büyükşehir belediye meclisi tarafından nazım imar planına uygunluğu yönünden incelenerek aynen veya değiştirilerek kabul edilmesi büyükşehir ilçe belediyelerini ikinci plana itmektedir” ifadesine verdiği cevaplara dağılımlarına göre incelendiğinde, \% 10,6's1 kesinlikle katılmıyorum, \% 26,4'ü katılmıorum, \% 22,2'si kararsızım, \% 24,1'i katılıyorum, \% 16,7'si de kesinlikle katılıyorum cevabını vermiştir. Buna göre, büyükşehir belediye meclislerinin ilçe belediye meclislerince alınan nazım imar planını denetleme yetkisinin olması ilçe belediyeleri için olumsuz bir durum olmadığı görüşünü ortaya çıkarmıştır.

İlçe belediye meclis üyelerinin "Büyükşehir ilçe belediyelerinin, mali açıdan büyükşehir belediye meclisi tarafindan denetlenmesi mali olarak serbest hareket edebilmesini sınırlamaktadır" ifadesine verdiği cevaplara göre dağılımları 
incelendiğinde, \% 13,0'ü kesinlikle katılmıyorum, \% 23,6's1 kesinlikle katılmıyorum, \% 25, 0'i kararsızım, \% 23,6'sı katılıyorum, \% 14,8'i kesinlikle katılıyorum cevabını vermiştir. Buna göre ilçe belediyelerinin mali yönden büyükşehir belediye meclisine denetimi ile ilgili kesin bir görüşe sahip olmadıkları görülmektedir.

İlçe belediye meclis üyelerinin "Büyükşehir belediyesinin büyükşsehir ilçe belediyelerine mali yardımının bazı şartlara bağlı olması mali olarak büyükşehir ilçe belediyelerinin elini büyükşehir belediyesi karşısında zayıflatacaktır" ifadesine verdiği cevaplara göre dağılımları incelendiğinde, \% 10,2'si kesinlikle katılmıyorum, \% 19,0'u katılmıorum, \% 20,8'i kararsızım, \% 32,9’u katılıyorum, \%17,1' kesinlikle katılıyorum cevabını vermiştir. Buna göre büyükşehir belediyesi tarafından ilçe belediyelerine yapılan mali yardımın bazı şartlara bağlı olması temelde ilçe belediyelerinin büyükşsehir belediyesine karşı gücünü zayıflatacağı görüşü ortaya çıkmıştır.

İlçe belediye meclis üyelerinin "Büyükşehir belediye meclisi karar alırken ilçe belediyelerinin görüş ve taleplerini dikkate alı" ifadesine verdiği cevaplara göre dağglımları incelendiğinde, \% 14,8'i kesinlikle katılmıyorum, \% 15,7'si katılmiyorum, \% 17,1'i kararsızım, \%40,7'si katılıyorum, \% 11,6'sı kesinlikle katılıyorum cevabını vermiştir. Buna göre büyükşsehir belediye meclisinin karar alırken ilçe belediyelerinin görüşlerinin önemsediği ortaya çıkmaktadır.

İlçe belediye meclis üyelerinin "Büyükşehir belediye meclisi aldığı kararlarında ilçe belediyelerinin çıkarlarını gözetir" ifadesine verdiği cevaplara göre dağılımları incelendiğinde, \% 13,4'ü kesinlikle katılmıyorum, \% 23,1'i katılmıyorum, \% 20,8'i kararsızım, \% 32,9'u katılıyorum, \% 9,7'si de kesinlikle katılıyorum cevabını vermiştir. Buna göre büyükşehir belediye meclisi aldığı kararlarda ilçe belediyelerinin çıkarlarını önemsediği/dikkate aldığı ortaya çıkmıştır.

İlçe belediye meclis üyelerinin "Büyükşehir ilçe belediye meclislerinin aldığı kararların yürürlüğe girebilmesi için büyükşehir belediye başkanına gönderilmesi uygulamasının kaldırılması büyükşehir genelinde birlikteliğin sağlanması konusuna zarar vermiştir" ifadesine verdiği cevaplara göre dağıllımları incelendiğinde, \% 10,6'sı kesinlikle katılmıyorum, \% 19,4'ü katılmıyorum, \% 38,9'u kararsızım, \% 24, 1'i katıliyorum, \% 6,9'u da kesinlikle katıliyorum cevabını vermiştir. Buna göre ilçe belediye meclislerinin almış oldukları kararların yürürlüğe girebilme şartı olan büyükşehir belediye başkanına gönderilmesi uygulamasının kaldırılmış olması bunun neticesinde büyükşehir genelinde birlikteliğin sağlanmasını olumsuz etkilediği hususunda kesin bir görüşe sahip olmadıkları görülmüştür. 
İlçe belediye meclis üyelerinin "İlçe belediye meclislerinde kararların (imar ve bütçe hariç) yürürlüğe girebilmesi için mülki idare amirine gönderilmesi mecburiyetinin meclis üzerinde herhangi bir baskı oluşturmadığını düşünüyorum" ifadesine verdiği cevaplara göre dağılımları incelendiğinde, \% 12,5'i kesinlikle katılmıyorum, \%13,0'ü katılmıyorum, \% 21,3'ü kararsızım, \% 39,8'i katılıyorum, \% 13,4'ü ise kesinlikle katılıyorum cevabını vermiştir. Buna göre, ilçe belediye meclislerince alınan kararların (imar ve bütçe hariç) yürürlüğe girmesi hususunda mülki idare amirliğine gönderilmesi zorluğunun olması ilçe belediye meclisleri için olumsuz bir durum ya da bir baskı unsuru teşkil etmediği ortaya çıkmıştır.

İlçe belediye meclis üyelerinin "İlçe belediye meclislerinde alınan kararların (imar ve bütçe hariç) yürürlüğe girebilmesi için mülki idare amiri yerine büyükşehir belediyesine gönderilmesi daha doğrudur" ifadesine verdiğgi cevaplara göre dağılımları incelendiğinde, \% 13,4'ü kesinlikle katılmıyorum, \% 18,5'i katılmıyorum, \% 29,2'si kararsızım, \% 31,0'i katılıyorum, \%7,9'u da kesinlikle katılıyorum cevabını vermiştir. Buna göre ilçe belediye meclislerince alınan kararların (imar ve bütçe hariç) yürürlüğe girmesinin mülki idare amiri yerine büyükşehir belediyesine gönderilmesinin daha doğru olacağı görüşü ortaya çıkmıştır.

İlçe belediye meclis üyelerinin "İlçe belediye meclislerinde alınan kararların (imar ve bütçe hariç) doğrudan yürürlüğe girmesi daha doğrudur" ifadesine verdiği cevaplara göre dağılımları incelendiğinde, \% 13,9'u kesinlikle katılmiyorum, \% 18,1'i katılmıyorum, \% 25,9'u kararsızım, \% 30,6's1 katıllyorum, \% 11,6'sı da kesinlikle katılıyorum cevabını vermiştir. Buna göre İlçe belediye meclisleri tarafından alınan kararların (imar ve bütçe hariç) doğrudan yürürlüğe girmesi görüşü ilçe belediye meclisi üyeleri tarafindan doğru bir uygulama olarak görülmektedir.

İlçe belediye meclis üyelerinin "İlçe belediye meclislerinde alınan kararların tümünün doğrudan yürürlüğe girmesi daha doğrudur" ifadesine verdiği cevaplara göre dağılımları incelendiğinde, \%16,7'si kesinlikle katılmıyorum, \%19,9'u katılmıyorum, \% 24,1'i kararsızım, \% 27,8'i katılıyorum, \% 11,6's1 da kesinlikle katıllyorum cevabını vermiştir. Buna göre ilçe belediye meclislerince alınan tüm kararların doğrudan hiçbir üst merciye danış1lmadan yürürlüğe girmesi gerektiği görüşü ortaya çıkmıştır.

\section{GENEL DEĞERLENDİRME ve SONUÇ}

$\mathrm{Bu}$ çalışma, büyükşsehir ilçe belediyelerinin özerkliğini Şanlıurfa ilçe belediyeleri örneği adı altında Şanlıurfa bazında ve ilçe belediyelerinin özerkliği özelinde ele almıştır. İlçe belediyelerinin özerkliğini ölçmeye yönelik olarak anket soruları hazırlanmıştır. Buna göre ilçe belediye meclis üyeleriyle hem 
yapılan anket hem de birebir yapılan görüşmeler neticesinde büyükşehir belediyeleri ile ilçe belediyeleri arasında yaşanan sorunlar ele alınmıştır.

Büyükşehirlerde Alt Yapı Ulaşım ve Koordinasyon Merkezlerine büyükşehir ilçe belediye başkanlarının sadece kendi belediyelerini ilgilendiren konularda katılmaları büyükşehir genelinde yönetime katılmayı sınırlar.

İlçe belediyelerinin kendilerine verilen görev ve yetkileri, hizmetleri verimli bir şekilde sunabilmeleri için ilçe belediye meclislerinin aldığı kararlar üzerinde "idari vesayet" yetkisi olmamalıdır. Kaldı ki ilçe belediyelerinin bir konu hakkında almış oldukları kararlar üzerinde denetim yetkisinin varlığı ilçe belediyelerinin özerkliği adına zedeleyici bir unsurdur. Yapılan araştırma neticesinde büyükşehir belediyesi ile ilçe belediyeleri arasında görev ve yetki paylaşımının net olması hususunda her ne kadar ankette görev ve yetkilerin net tanımlandığını sonucuna varılsa da yapılan görüşmelerde bu konuda büyükşehir belediyesi ile sorunlar yaşandığ belediyesine uzak mesafede olan ilçeler bu hizmetlerin sunumunda uzaklığa bağlı olarak gecikmeler yaşandığını belirtmiş̧ir. Bu konuda hizmette yakınlık ilkesi gereğince, hizmet sunumunun daha verimli ve daha kaliteli yapılması adına büyükşehir belediyesi kendisine uzak mesafede olan ilçe belediyelerine yapılacak olan hizmetin sunumuna yönelik olarak yetki vermelidir.

İmar uygulama ve denetleme yetkisinin büyükşehir belediyesinde olması, kentin planlamas1, kaynak ve zaman israfi gibi olumsuz durumları ortadan kaldıracaktır. Nitekim yapılan araştırmada da ilçe belediyeleri bu konuda imar uygulama ve denetleme yetkisinin büyükşehir belediyesinde olması gerektiği görüşünü savunmuşlardır. Buna ek olarak ilçe belediyeleri imar gibi kentin geleceğini inşa eden önemli bir konuda, tüm yetkilerin büyükşehir belediyesinde olmasında kendilerinin geri planda kaldığını belirtmişlerdir. Kaldı ki ilçe belediyelerinin kendi ihtiyaçlarına yönelik olarak imar ve planlama konusunda, söz sahibi olmak istemektedirler. İlçe belediyeleri ilçenin bizzat ihtiyaçlarının belirlenmesinde büyükşehir belediyesine göre daha çok bilgi ve tecrübe sahibidirler. $\mathrm{Bu}$ anlamda yetkinin bir bölümünün ilçe belediyelerinde olması, imara yönelik ilçe belediyeleri ile büyükşehir belediyesi arasında yaşanan sorunları azaltacaktır.

Büyükşehir belediyesinin ilçe belediyelerine mali yardımının bazı şartlara bağlı olarak yapılması, ilçe belediyelerinin elini büyükşehir belediyelerine karşı zayıflatacaktır. İlçe belediyelerine mali yardımın şarta bağlı olarak yapılması Avrupa Yerel Yönetimler Özerklik Şartı'na aykırı bir durumdur. Kaldı ki Avrupa Yerel Yönetimler Özerklik Şartı zayıf olan yerel yönetim birimine şarta bağlı olmadan mali yardımın yapılmasını öngörür. Böylece zayıf olan yerel yönetim birimi güçlü olan diğer yönetim birimleriyle aynı duruma gelir. İlçe belediyeleri 
yerinden yönetim adına ilçede vatandaşların ihtiyaçları doğrultusunda hizmet sunmakla görevlidir. Şarta bağlı bir yardım durumunda öncelikli amacın dışına çıkılacağ 1 gibi ilçede vatandaşlar tarafindan ciddi anlamda eleştiriye maruz kalabilirler. Bu uygulama, mali özerklik ile uyuşmayan bir durumdur. İlçe belediyelerine yardımın şartsız olarak verilmesi gerekir. Bu anlamda ilçe belediyeleri kendi ihtiyaçları doğrultusunda herhangi bir baskı olmadan kaynaklarını ihtiyaçları doğrultusunda gerektiği gibi kullanabilmelidir.

İlçe belediye meclisleri aldıkları kararlarda, mülki idare amirine gönderilmesinde meclis kararları üzerinde herhangi bir baskı oluşturmayacağını bununla beraber mülki idare amirine göndermek yerine alınan kararların büyükşehir belediyesine gönderilmesinin daha doğru olacağını savunmuşlardır.

Sonuç olarak büyükşsehir belediyesi ile ilçe belediyeleri arasındaki ilişkilerin özerklik temelli gelişmesi gerekir. Yapılan araştırma sonucunda ilçe belediye meclis üyeleri belirli sınırlar içerisinde büyükşehir belediyesinin kendilerine çok fazla müdahale etmemeleri doğrultusunda isteklerini dile getirmişlerdir.

\section{KAYNAKÇA}

Alıc1, Orhan Veli ve Kızılboğa Özaslan, Rüveyda (2017), “íki Kademeli Büyükşehir Yönetim Sisteminin Yargı Kararları Kapsamında İncelenmesi”, Belediyelerin Geleceği ve Yeni Yaklaşımlar, (Der. Güler, Mahmut ve Turan, A. Menaf), Marmara Belediyeler Birliği Yayınları, İstanbul, ss. 225-267.

Alıc1, Orhan Veli (2012a), "Büyükşehir Belediyeleri ile İlçe Belediyeleri Arasındaki İlişkiler: İstanbul Örneği”, Yayınlanmamış Doktora Tezi, İstanbul Üniversitesi Sosyal Bilimler Enstitüsü, İstanbul.

Alıc1, Orhan Veli (2012b), "Büyükşsehir Belediyelerinin İlçe Belediyeleri Üzerindeki Denetim Yetkisinin Kavramsal Açıdan Değerlendirilmesi”, Yerel Politikalar Dergisi, Sayı: 2, Mayıs-Ağustos, ss. 38-52.

Alıc1, Orhan Veli (2013), "Büyükşehir İlçe Belediyelerinin İdari ve Mali Özerkliği”, Yerel Politikalar Dergisi, Sayı: 3, Ocak-Haziran, ss. 127-152.

Alodal1, M.Fatih Bilal - Özcan, Lütfi - Çelik, Fikret - Usta, Sefa (2007), “Avrupa Yerel Yönetimler Özerklik Şartı ve Türkiye'de Belediyelerde Özerklik”, Selçuk Üniversitesi Karaman İktisadi İdari Bilimler Dergisi Yerel Ekonomiler Özel Sayıs1, Haziran, ss. 1-11. 
Coşkun, Bayram (1996), “Türkiye'de İdari Vesayet Denetimi ve Yerel Yönetimlerin Özerkliğ̣i”, Çağdaş Yerel Yönetimler Dergisi, Cilt. 5, Sayı: 3, May1s, ss. 35-47.

Çelik, Abdullah (2013), "Yerel Özerklik Açısından 5393 sayılı Belediye Kanunun Genel Bir Değerlendirmesi”, Süleyman Demirel Üniversitesi İktisadi ve İdari Bilimler Fakültesi Dergisi, Cilt. 18, Sayı: 1, ss. 17-28.

Çelik, Vasfiye- Çelik, Fikret - Usta, Sefa (2008), "Yerel Demokrasi ve Yerel Özerklik İlişkisi”, Niğde Üniversitesi İktisadi ve İdari Bilimler Fakültesi Dergisi, Cilt. 1, Sayı: 2, Aralık, ss. 87-104.

Egeli, Halûk ve Diril, Funda (2012), “Türkiye’de Yerel Yönetimlerde Mali Özerklik ve Vergilendirme Yetkisi”, Sayıştay Dergisi, Sayı: 84, Ocak-Mart, ss. 25-44.

Ekici, Birol ve Toker, M. Cem (2005), “Avrupa'da ve Ülkemizde Yerel Yönetimlerin Denetimi ve Etkinliği”, Çağdaş Yerel Yönetimler Dergisi, Cilt. 14, Say1: 1, Ocak, ss. 5-28.

Erençin, Arif (2005), "Büyükşsehirlerde Belediyeler Arası İlişkilerin Yenilenen Yapısı", Mülkiye Dergisi, Cilt. 29, Sayı: 246, ss. 121-131.

Karasu, Mithat Arman (2013), "Büyükşehir İlçe Belediyelerinin Özerklik Sorunu", Beşinci Ulusal Yerel Yönetimler Sempozyumu, (Der. Mengi, Ayşegül- Çınar, Tayfun- Özgül, Can Giray), Türkiye Belediyeler Birliği Yayınları, Ankara, ss. 475-502.

Kavruk, Hikmet ve Yaylı, Hasan (2008), “2004 Belediye Reform Çalışmalarında İdari Vesayete İlişkin Düzenlemelerin Değerlendirilmesi ve Bir Araştırma", Gazi Üniversitesi İktisadi İdari Bilimler Fakültesi Dergisi, Cilt. 10, Say1: 3, ss. 1-31.

Keleş, Ruşen (2016), Yerinden Yönetim ve Siyaset, Cem Yayınevi, İstanbul.

Kestane, Doğan (1996), “iller Bankası ve Yerel Yönetimlerle İliş kileri”, Devlet Bütçe Uzmanlığı Araştırma Raporu, T.C. Maliye Bakanlığı Bütçe ve Mali Kontrol Genel Müdürlüğ̈̈, Ankara.

Koç, Firdevs (2015), “Türkiye'de Yerel Yönetimlerde Yerel Özerklik ve İdari Vesayet”, Yayınlanmamış Doktora Tezi, İnönü Üniversitesi Sosyal Bilimler Enstitüsü, Malatya.

Tortop, Nuri (1996), “Yerel Yönetimler ve Mali Özerklik”, Çağdaş Yerel Yönetimler Dergisi, Cilt. 5, Sayı: 5, Eylül, ss. 3-13. 
Ulusoy, Ahmet ve Akdemir, Tekin (2009), "Yerel Yönetimler ve Mali Özerklik: Türkiye ve OECD Ülkelerinin Karşılaştırmalı Analizi”, Balıkesir Üniversitesi Sosyal Bilimler Enstitüsü Dergisi, Cilt. 12, Sayı: 21, Aral1k, ss. 259-287. 